OPEN ACCESS

Edited by:

Kai-Jun Zhang,

University of Chinese Academy of

Sciences, China

Reviewed by:

Peng Yang,

Northwest University, China

Yu Qi,

Yanshan University, China

*Correspondence:

Thitiphan Assawincharoenkij thitiphan.a@chula.ac.th

Specialty section: This article was submitted to Geochemistry,

a section of the journal

Frontiers in Earth Science

Received: 23 September 2021 Accepted: 27 December 2021 Published: 13 January 2022

Citation:

Chenrai P, Assawincharoenkij T, Warren J, Sa-nguankaew S,

Meepring S, Laitrakull $K$ and Cartwright I (2022) The Occurrence of Bedding-Parallel Fibrous Calcite Veins in Permian Siliciclastic and Carbonate

Rocks in Central Thailand.

Front. Earth Sci. 9:781782.

doi: 10.3389/feart.2021.781782

\section{The Occurrence of Bedding-Parallel Fibrous Calcite Veins in Permian Siliciclastic and Carbonate Rocks in Central Thailand}

\author{
Piyaphong Chenrai ${ }^{1,2}$, Thitiphan Assawincharoenkij ${ }^{1 *}$ John Warren ${ }^{2}$, \\ Sannaporn Sa-nguankaew ${ }^{2}$, Sriamara Meepring ${ }^{1}$, Kasira Laitrakull ${ }^{3}$ and lan Cartwright ${ }^{4}$ \\ ${ }^{1}$ Applied Mineral and Petrology Special Task Force for Activating Research (AMP STAR), Department of Geology, Faculty of \\ Science, Chulalongkorn University, Bangkok, Thailand, ${ }^{2}$ M.Sc. Program in Petroleum Geoscience, Faculty of Science, \\ Chulalongkorn University, Bangkok, Thailand, ${ }^{3}$ PTT Exploration and Production, Bangkok, Thailand, ${ }^{4}$ School of Earth Atmosphere \\ and Environment, Monash University, Melbourne, VIC, Australia
}

Bedding-parallel fibrous calcite veins crop out at two Permian carbonate localities in the Phetchabun area, central Thailand, within the Nam Duk and Khao Khwang Formations. Samples are studied to determine their petrographic, geochemical and isotopic character, depositional and diagenetic associations and controls on the formation of fibrous calcite across the region. Biomarker and non-biomarker parameters are used to interpret organic matter sources in the vein-hosting units, the depositional environment and levels of source rock maturation in order to evaluate source rock potential in the two Formations. Carbon and oxygen isotope values of the veins and the host are determined to discuss the source of carbonates and diagenetic conditions. The petroleum assessment from the Khao Khwang and Nam Duk Formations suggests that both Formations are a petroleum potential source rock with type II/III kerogen deposited in an estuarine environment or a shallow marine environment and a slope-to-basin marine environment or an open marine environment, respectively. The bedding-parallel fibrous calcite veins from the Khao Khwang and Nam Duk Formations are divided into two types: 1) beef and, 2) cone-incone veins. The carbon and oxygen isotope compositions from the fibrous calcite veins suggest that the calcite veins could be precipitated from a carbon source generated in the microbial methanogenic zone. The results in this study provide a better understanding of the interrelationship between the bedding-parallel fibrous calcite veins and petroleum source rock potential.

Keywords: fibrous calcite vein, stable isotope, petroleum source rock, Permian carbonate platform, petrography

\section{INTRODUCTION}

Bedding-parallel fibrous calcite veins are found in sedimentary rocks from Cambrian to Palaeogene strata in many locations worldwide (Cobbold and Rodrigues, 2007; Cobbold et al., 2013; Heindel et al., 2015; Kershaw and Guo, 2016; Ma et al., 2016; Cabral et al., 2019). Rocks hosting the veins are typically mixed siliciclastic-carbonate rocks, such as calcareous mudstones, argillaceous limestones and lime muds consistently rich in organic matter with low permeabilities (Franks, 1969; Cobbold and Rodrigues, 2007; Rodrigues et al., 2009; Cobbold et al., 2013; Heindel et al., 2015; Meng et al., 
2017; Tribovillard et al., 2018). Such fibrous calcite veins are globally identified across organic-entraining sedimentary basins, and are used in petroleum exploration as monitors of hydrocarbon generation (e.g., Zanella, and Cobbold, 2012; Meng et al., 2017; Luan et al., 2019; Zhang et al., 2021). Despite many studies of these veins, their origin is still debated; many studies infer the veins relate to overpressuring at times of hydrocarbon generation (e.g., Warren et al., 1998; Zhang et al., 2016; Meng et al., 2017; Luan et al., 2019). Other studies suggest the veins precipitate in unconsolidated sediments at shallow depth beneath the seafloor during times of increased concentrations of carbon dioxide in seawater and the atmosphere (Greene et al., 2012; Heindel et al., 2015; Kershaw and Guo, 2016). Times of elevated carbon dioxide concentration are generally associated with mass extinction events, including end-Permian (P-T) boundary and the end-Triassic (T-J) boundary, and are tied to large scale volcanic eruptions (e.g., Greene et al., 2012; Kershaw and Guo, 2016).

The studied fibrous calcite veins are divided into two endmembers; 1) beef and, 2) cone-in-cone veins (Cobbold et al., 2013). Calcite beef vein contains subvertical fibrous calcite crystals perpendicular to bedding in the host rock, with a smooth boundary between the host rock and the vein. Cone-incone veins generally consist of conical bundles of calcite fibrous representing a crystal growth character radiating from the bedding plane of the host rock. The mechanism of the calcite vein development is interpreted open-fracture fill into accommodation space created once pore pressure exceeds lithostatic pressure and hydrofracturing occurs (Zanella and Cobbold, 2012; Cobbold et al., 2013). The overpressure process can be driven by sediment degassing, especially in organic-rich rocks with low permeability, or during hydrocarbon generation (Osborne and Swarbrick, 1997; Simms, 2004; Zhang et al., 2016).

Bedding-parallel fibrous calcite veins have been found (this study) within petroleum carbonate source rocks in Thailand. In addition, the carbonate rocks hosted the fibrous calcite veins are believed to be the main petroleum source rock that contributes hydrocarbons to commercial gas fields in the Khorat Plateau located in northeast Thailand (Racey, 2011). These carbonate source rocks are Permian rocks having hydrocarbon peak generation in Late Triassic (Kozar et al., 1992). Thus, the fibrous calcite veins from this study could contribute to the ongoing discussion on the forming mechanism of fibrous calcite veins and their use as potential indicators of hydrocarbon expulsion in sedimentary basins. Carbon and oxygen isotope signatures of calcite veins offer valuable information as to the nature of changing fluid activity and geochemistry in sedimentary basins during diagenesis. Recent publications of isotope studies of fibrous calcite crystals in sedimentary basins have quantified formation mechanisms and the nature of parent waters (e.g., Demeny et al., 2010; Yu et al., 2015; Hooker et al., 2019; Luan et al., 2019).

This paper is the first to document and quantify beddingparallel fibrous calcite veins in Thailand. It is part of our groups ongoing geochemical and isotopic documentation of Permian carbonate and siliciclastic rocks in Thailand. The aim of this study is to describe characteristics of the calcite fibrous veins and to assess the petroleum source rock potential of the hosting finegrained Permian carbonates. Results of our study are relevant to petroleum exploration in the region and worldwide.

\section{GEOLOGICAL BACKGROUND}

Permian carbonates in central Thailand are exposed along the western edge of the Khorat Plateau (Figure 1). Permian rocks in this region consist of three major elements: the Khao Khwang Platform, the Pha Nok Khao Platform and the Nam Duk Basin located in the west, the east and middle of the Loei-Phetchabun Fold Belt, respectively (Wieldchowsky and Young, 1985; Figure 1A). Geologically, the Permian carbonate rocks are interpreted as a suite of Permian rift basins on the southern margin of the Indochina terrane, controlled by extensional faults (Booth and Sattayarak, 2011; Morley et al., 2013). The Indochina terrane drifted away from the northern margin of Gondwana by the Early-Middle Permian (Yan et al., 2018). Both Permian carbonate platforms, Khao Khwang and Pha Nok Khao, are extensive, distally-steepened ramps, composed of varying proportions of carbonates and lesser siliciclastics. Based on outcrop data, in what is a structurally complex orogenic region, a simplified regional model is made up of a siliciclastic-rich Nam Duk basin lies adjacent to and separates two large carbonate-dominant platforms (Wieldchowsky and Young, 1985; Figure 1A). To the south, the Nam Duk Basin also forms outer western boundary of the Indochina terrane. Our study focuses on the carbonates and siliciclastic rocks of the Khao Khwang and Nam Duk Formations that crop out in this area (Udchachon et al., 2014).

The Khao Khwang Formation was deposited in a shallowmarine carbonate platform characterized by mixing of carbonate rocks (massive to medium-to-thick, well-bedded to muddy limestones) mixed with siliciclastic sediments (Nakornsri, 1981; Ridd et al., 2011). The age of the Khao Khwang Formation is late Early Permian (Kungurian) to early Middle Permian (Guadalupian) (Metcalfe and Sone, 2008; Chitnarin et al., 2012). To the east, the somewhat deeper water Nam Duk Formation is dominated by siliciclastic and pelagic rocks of Early to Late Permian age, deposited in a slope-to-basin marine environment (Booth and Sattayarak, 2011; Ueno and Charoentitirat, 2011). The Nam Duk Formation comprises cherts, tuffs, shales, sandstones and calci-turbidites and limestone-dominated mass transport deposits (Helmcke and Kraikhong, 1982; Chonglakmani, 2005; Vattanasak et al., 2020). At the end of the Guadalupian across the Khao Khwang Platform, the limestone sequence is truncated by two major erosional surfaces which were responses to global sea-level lowstands (Udchachon et al., 2014). Tectonic uplift in parts of the Loei-Phetchabun Fold Belt began around the Guadalupian-Lopingian boundary and continued up to the Triassic (e.g., Bunopas, 1983; Chonglakmani and Sattayarak, 1984; Chonglakmani and Helmcke, 2001). Permian strata are now separated from overlying Mesozoic sediments by the Indosinian I unconformity; moreover, most Paleozoic strata in 

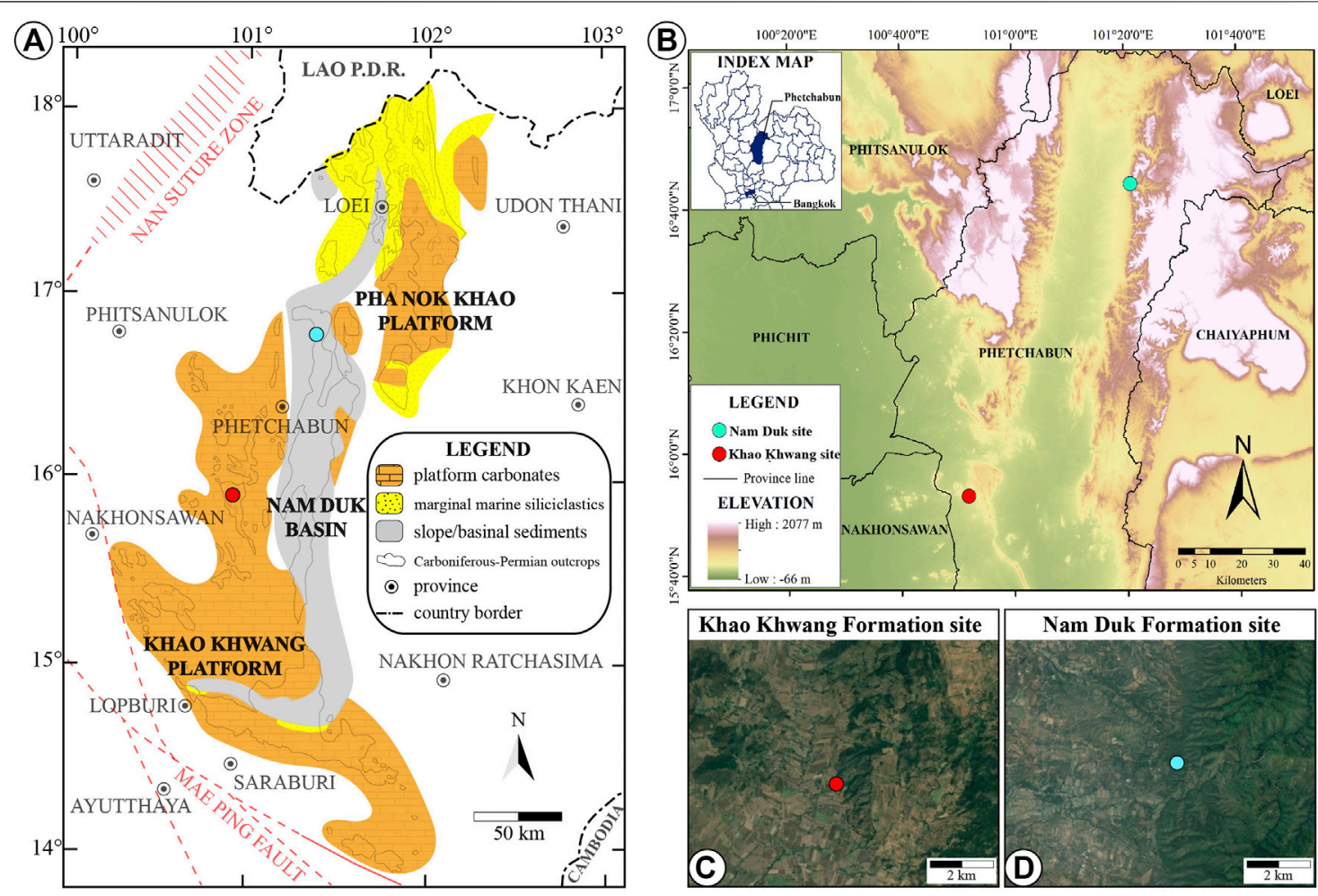

FIGURE 1 | (A) distribution of the Permian rocks, the Khao Khwang and Pha Nok Khao Platforms, separated by the Nam Duk Basin in the Loei-Phetchabun Fold Belt, central Thailand (modified from Ueno and Charoentitirat, 2011); (B) sample locations (Nam Duk and Khao Khwang sites) in Phetchabun Province, Thailand; (C) sample collection at Khao Khwang Formation; (D) sample collection at Nam Duk Formation.

the region were widely deformed during this same Indosinian I event (Ridd et al., 2011).

Potential source rocks in these Formations are both marine shales and micritic limestones and are known to be regionally extensive throughout the various Permian carbonate platforms (Racey, 2011; Chenrai and Fuengfu, 2019). Although Permian source rocks, based on limited well and outcrop data, are interpreted as thermally overmature with peak generation in Late Triassic (Kozar et al., 1992), regionally they are still attractive, with potential for further exploration in central and northern Thailand.

\section{MATERIALS AND METHODS}

\subsection{Field Sampling and Sample Preparation}

Field study and rock sampling are performed in two study areas in Phetchabun Province (Figure 1B). In total, 12 rock samples were selected for detailed study from a range of samples from the Khao Kwang and Nam Duk Formations. The 12 samples contained fibrous calcite veins suitable for petrography and geochemical analyses. Generally, bedding-parallel fibrous calcite veins documented in this study occur within calcareous mudstones and argillaceous limestones. Samples referred to as "outcrop samples" in this paper are not taken directly from the surface. Instead, samples were collected by digging some 0.10 and $0.30 \mathrm{~m}$ into the outcrop to ensure that visibly unweathered material was obtained. Any remaining weathered parts of the samples were removed before proceeding with detailed analysis. Samples were then cleaned with distilled water, acetone, and dichloromethane to eliminating any remaining surface contamination. All washed samples for organic geochemical analysis were crushed into small chips in a hammer and jaw-crusher and then into powder by dish mill grinder. Powder samples were then put into pre-washed glassware for further extractable organic matter and gas chromatography-mass spectrometric determinations. Petrographic samples were cut into rock slabs, and thin sections were made to observe fibrous calcite characteristics. Samples for isotope analysis were extracted from vein regions in rock slabs by using a dental technician's drill in traverses that extracted a sample volume every $5 \mathrm{~mm}$ along traverses than ran from the host rock across a vein, or stacked veins, and back into host rock on the other side of the vein.

\subsection{Gas Chromatography-Mass Spectrometry}

Gas chromatography-mass spectrometry (GC-MS) is an instrumental technique for identifying the molecular mass of organic compounds by their ionized compositions. In this study, GC-MS was performed at the Scientific and Technological Research Equipment Centre Chulalongkorn University to 
analyze biomarker and non-biomarker compounds from bitumen extracts. The saturated hydrocarbon fraction from the rock samples was dissolved in n-pentane and analyzed with an Agilent 7000C GC/MS (triple quadrupole) machine, with an ion source temperature of $250^{\circ} \mathrm{C}$ and ionizing energy of $70 \mathrm{eV}$. The column used in this study is a $30 \mathrm{~m}$ long DB-5 (5\% Phenyl Methyl Siloxane) with a $250 \mu \mathrm{m}$ inner diameter and $0.25 \mu \mathrm{m}$ film thickness. Starting temperature is $80^{\circ} \mathrm{C}$ and is held for $3 \mathrm{~min}$. The column temperature is heated from $80^{\circ} \mathrm{C}$ to $310^{\circ} \mathrm{C}$ at $4^{\circ} \mathrm{C} /$ minutes and held for $30 \mathrm{~min}$ at $310^{\circ} \mathrm{C}$. The total analysis time is $90 \mathrm{~min}$. Chromatograms were acquired in scanning: 35-700 molecular weight and selected-ion-monitored (SIM) for compound identification and integration. The distribution of organic compounds in the bitumen extracts was monitored by fragmentograms of $n$-alkane $(\mathrm{m} / \mathrm{z} 85)$ and steranes $(\mathrm{m} / \mathrm{z} 217)$. Details of the analytical procedure used are summarized in Moustafa and Morsi (2012).

\subsubsection{Long-Chain Saturated Hydrocarbon (n-Alkane) Distribution}

Chromatogram distribution of $n$-alkane and isoprenoids from the saturated hydrocarbon extraction displays aliphatic fractions of all analyzed samples. The distribution of $n$-alkanes can be used to indicate organic matter source. Short chain $n$-alkanes (lower than $\mathrm{C}_{20}$ ) are characteristic of microbial input. In addition, medium chain $n$-alkanes $\left(\mathrm{C}_{11}-\mathrm{C}_{20}\right)$ are considered to indicate algal and/or bacterial origin for the organic materials. Long chain $n$-alkanes (more than $\mathrm{C}_{20}$ ), high boiling point $n$-alkanes, are commonly attributed to the contribution of terrestrial waxes, especially in the $\mathrm{C}_{25}-\mathrm{C}_{33}$ range (Peters and Moldowan, 1993). In this study, the $\mathrm{Pr} / \mathrm{Ph}, \mathrm{Pr} / \mathrm{n}-\mathrm{C}_{17}$ and $\mathrm{Ph} / \mathrm{n}-\mathrm{C}_{18}$ outputs are also used for determining the source of organic matter and conditions in the depositional environment (e.g., Shanmugam, 1985; Wang et al., 2010; Al-Khafaji et al., 2020). Biomarker parameters used in this study are presented as follows:

1) Pristane $\left(\mathrm{C}_{19} \mathrm{H}_{40}\right)$ and phytane $\left(\mathrm{C}_{20} \mathrm{H}_{42}\right)$ are regular isoprenoid hydrocarbons, which both were derived from the phytol side chain of chlorophyll molecule (Miles, 1989). Pristane and phytane ratio $(\mathrm{Pr} / \mathrm{Ph})$ is commonly used for determining redox conditions and organic matter inputs in various depositional environments during sedimentation and diagenesis (Powell, 1988; Chandra et al., 1994; Large and Gize, 1996). High $\mathrm{Pr} / \mathrm{Ph}$ values (>3.0) indicates oxic conditions often associated with terrigenous organic matter input, while low values $(<1.0)$ typify anoxic conditions, commonly hypersaline or carbonate environments and values between 1.0 and 3.0 suggest intermediate conditions (sub-oxic conditions) (Amane and Hideki, 1997; Peters et al., 2005). In addition, $\mathrm{Pr} / \mathrm{Ph}$ ratio can be used to indicate lithology from analyzed samples, for instance, marine carbonates $(\mathrm{Pr} / \mathrm{Ph}<1)$, marine shales ( $\mathrm{Pr} / \mathrm{Ph} \mathrm{1-3),} \mathrm{and} \mathrm{non-marine} \mathrm{shales/coals}(\mathrm{Pr} /$ $\mathrm{Ph}>$ 3) (Hughes et al., 1995).

2) The combination of acyclic isoprenoids compared to $n$-alkanes $\left(\mathrm{Pr} / \mathrm{n}-\mathrm{C}_{17}\right.$ and $\left.\mathrm{Ph} / \mathrm{n}-\mathrm{C}_{18}\right)$ provides valuable information about organic matter source, biodegradation, maturation and depositional environment. In general, isoprenoids are more resistant to biodegradation than $n$-alkanes, and are used to determine any influence from early microbial degradation (Landais, 1996). Moreover, the $\mathrm{Ph} / \mathrm{n}-\mathrm{C}_{17}$ ratio tends to be less than 0.5 in environments with abundant aerobic bacterial activity, whereas values of more than 1 tend to indicate low levels of aerobic bacterial activity (Lijmbach, 1975).

3) Sterane biomarker measures indicate carbon number distribution of sterols that can be used to interpret organic matter source and depositional environment by plotting regular sterane compositions $\left(\mathrm{C}_{27}, \mathrm{C}_{28}\right.$ and $\left.\mathrm{C}_{29}\right)$ in a tertiary diagram (Huang and Meinschein, 1979; Moldowan et al., 1985; Shanmugam 1985). The domination of $\mathrm{C}_{27}$ steranes represents a marine-influenced system and marine plankton, $\mathrm{C}_{28}$ sterane predominance suggests an organic matter deposited in lacustrine facies, and the influence of $\mathrm{C}_{29}$ sterane suggests a terrestrial environment as higher plant input and a swamp deposit environment (Peters and Moldowan, 1993).

\subsection{Carbon and Oxygen Stable Isotope Analysis}

Stable isotopes of $\delta^{13} \mathrm{C}$ and $\delta^{18} \mathrm{O}$ of the veins and host rock samples are measured by utilizing techniques outlined in Allègre (2008) after extracting powder samples using a dental technician's drill. The stable isotopes were carried out at Monash University, Australia. The purpose of this study is to better understand fluid carbon sources for the fibrous calcite veins and fluid evolution during different burial stages, tied to calcite precipitation. The carbon sources for the fibrous calcite vein in organic-rich rocks come from inorganic carbon in the host sediment and organic carbon from organic matter (both depositional and catagenic). The inorganic carbon source is expected to have $\delta^{13} \mathrm{C}$ values near the seawater $\delta^{13} \mathrm{C}$ value through time, whereas the organic carbon source is significantly depleted in the host rock by biological processes (Luan et al., 2019). Therefore, if no external fluids contributed to the host rock, especially within low permeability host rocks, the fibrous calcite vein is expected to have bulk isotopic compositions close to the host rock. All analyses are reported in per mill (\%o) relative to the Vienna-PeeDee Belemnite (V-PDB) standard.

\section{RESULTS}

\subsection{Bedding Parallel Fibrous Character}

The dominant lithology of samples from the Khao Khwang Formation is argillaceous limestone. In general, the succession in the study area comprises limestone (approximately $1-50 \mathrm{~cm}$ ) interbedded with calcareous mudstone to argillaceous limestone (approximately $1-10 \mathrm{~cm}$ ) (Figures 2A,B). In contrast, the rock samples from the Nam Duk Formation are calcareous mudstones interbedded with sandstones (Figures 2C,D). Beddingparallel fibrous calcite veins are around $1-7 \mathrm{~cm}$ from 

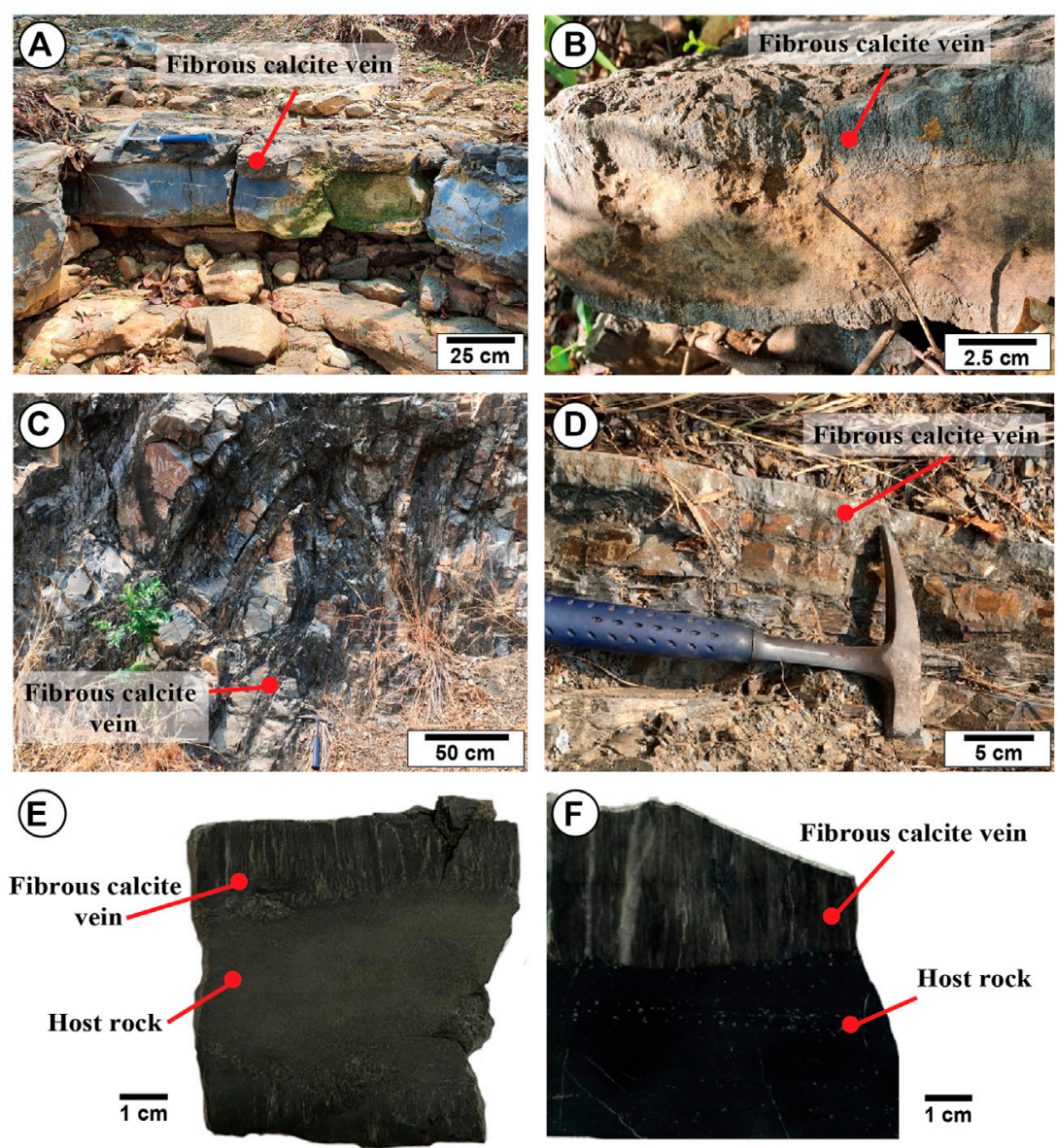

FIGURE 2 | (A),(B) the fibrous calcite veins of the Khao Khwang Formation; (C),(D) the fibrous calcite veins of the Nam Duk Formation; (E),(F) polished slab of bedding-parallel fibrous calcite veins from the Khao Khwang Formation (E) and the Nam Duk Formation (F).

exposed bedding plane surfaces in their host rock outcrops (Figures 2E,F) and oriented approximately parallel to the inferred bedding planes in both Khao Khwang and Nam Duk Formations (Figures 2E,F).

\subsubsection{Khao Khwang Formation}

Both types of the fibrous calcite vein (beef and cone-in-cone) are observed in this Formation, but cone-in-cone veins tend to dominate. Most fibrous calcite crystals commonly entrain solid inclusions composed of variable proportions of insoluble mud components, organic matter, and pyrite (Figure 3A). In some samples, cone-in-cone veins and granulars grade into beef veins at the base of the cone interval (Figures 3A,B). Generally, solid (host-mud) inclusions outline sinusoidal patterns within the fibrous calcite of the cone-in-cone vein intervals (Figure 3C). In contrasts, there are few to no solid inclusions in the beef veins (Figure 3D). Accompanying pressure solution features are seen in the host rock matrix in Khao Khwang samples, especially stylolites and microstylolite (Figure 3E). Framboidal pyrite ranging from 5.7 to $65 \mu \mathrm{m}$ is common in most recrystallized host rock (Figure 3F).

\subsubsection{Nam Duk Formation}

In contrast to the Khao Khwang samples, fibrous calcites in the Nam Duk Formation are mostly in beef veins, with sharp contacts with the adjacent the host rock surfaces (Figure 4A). A median suture line is observed in the Nam Duk vein samples indicating the growth direction of the fibrous calcites (Figure 4B). The fibrous calcite crystals have widths around $0.2-1.0 \mathrm{~cm}$, with twinning (Figure 4C). Solid inclusions are indistinctive to absent in the samples from this Formation. When present they are mostly small amounts of insoluble clay minerals, organic matter and pyrite. In addition, irregular quartz vein crystals are found in the calcite veins and in the siliciclastic rock matrix of this Formation (Figure 4C). Shear deformation is seen in sand grains floating in a clay-dominated matrix (Figure 4D). Pyrite is also present within the host rocks in various forms, including euhedral, framboidal, and aggregate framboid morphologies ranging from 0.1 to $0.5 \mathrm{~mm}$.

\subsection{Molecular Geochemistry}

The quality of TOC and pyrolysis data as published in previous studies, using standard petroleum industry methodologies, is 

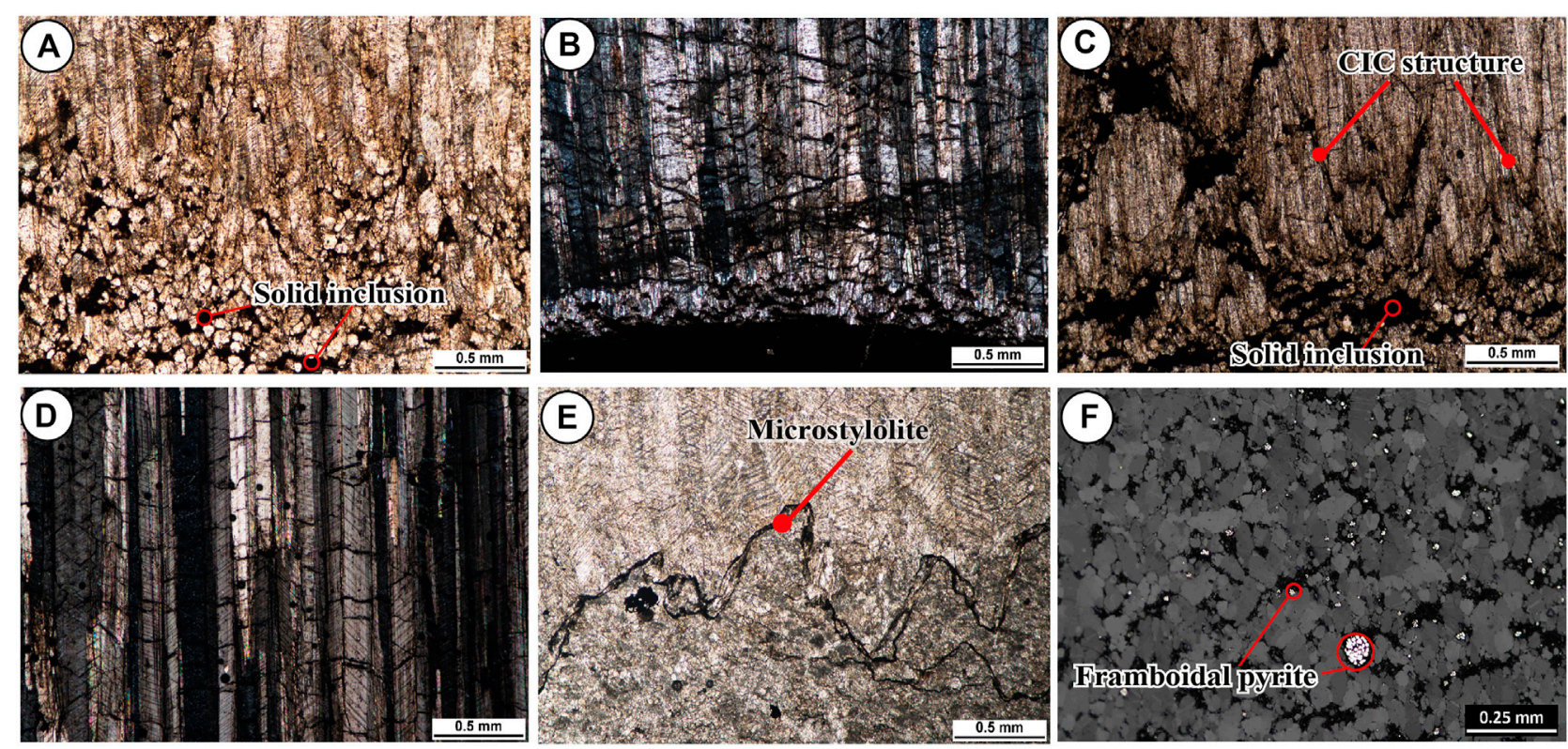

FIGURE 3|Photomicrographs of the Khao Khwang Formation. (A) Solid inclusions in the fibrous calcite vein and a change from equant calcite to fibrous calcite; (B) a change from cone-in-cone to beef vein textures; (C) beef veins in the Khao Khwang samples; (D) cone-in-cone veins are commonly found in the Khao Khwang samples and are characterized by a nested cone geometry; (E) microstylolite; and (F) framboidal pyrite is common in the host rock matrix.
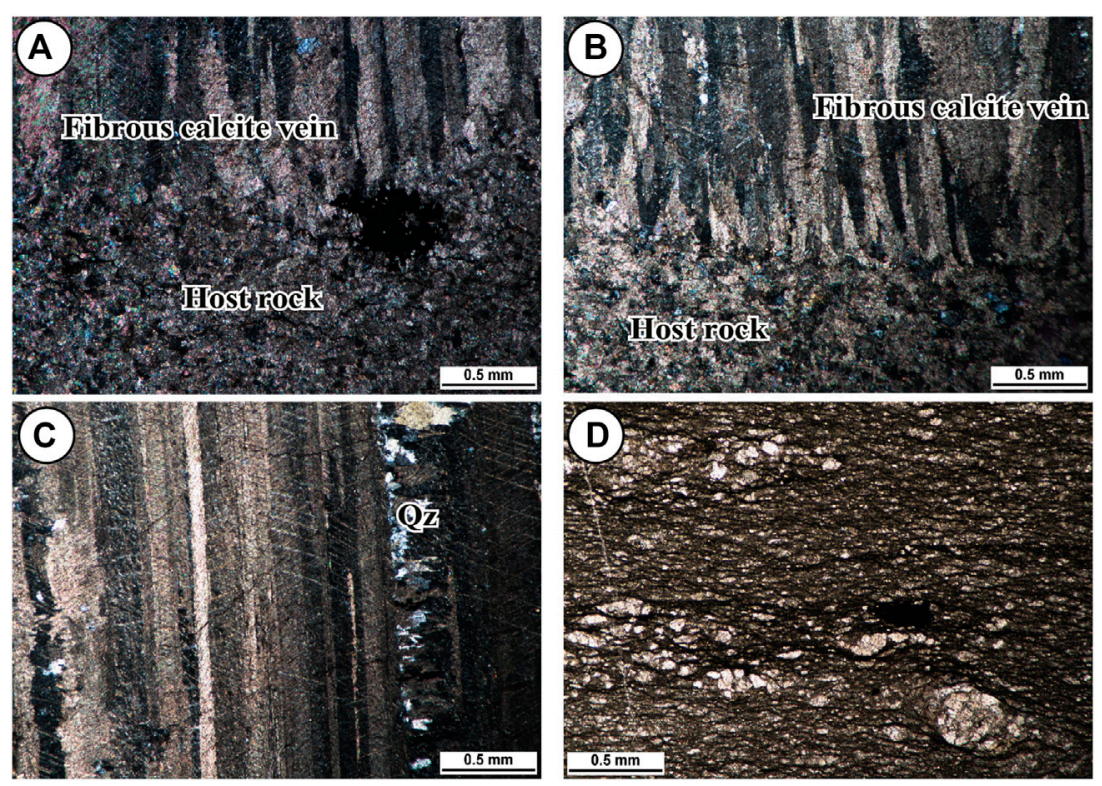

FIGURE 4 | Photomicrographs of the Nam Duk Formation. (A) Beef veins typify the Nam Duk samples; (B) a change from the host rock to beef vein with a median suture line; (C) calcite twining in beef vein associated with quartz crystals; (D) sand grains floating in the host rock matrix.

compromised, likely due to strong maturation (e.g., Chenrai and Fuengfu, 2019). Accordingly, in this study, organic matter source and the depositional conditions are determined using alternative tools such as non-biomarker and biomarker parameters. Molecular geochemical results and biomarker ratios from samples measured in this study are summarized in Table $\mathbf{1 .}$

\subsection{1 n-Alkanes Distribution}

Gas chromatograms of saturated hydrocarbon fractions from the analyzed samples are shown in Figure $\mathbf{5}$ and display a full suite of saturated hydrocarbons including $\mathrm{C}_{8}-\mathrm{C}_{35} n$-alkanes, isoprenoids, pristane $(\mathrm{Pr})$ and phytane $(\mathrm{Ph})$. The $n$-alkane distribution from the two Formations suggests that the 
TABLE 1 | The molecular geochemical results and biomarker ratios of the Khao Khwang $(\mathrm{KK})$ and Nam Duk (ND) samples. $\mathrm{C}_{27}, \mathrm{C}_{28}$ and $\mathrm{C}_{29}$ are regular sterane compositions converted to a percentage.

\begin{tabular}{lcccccc}
\hline Sample & $\mathbf{P r} / \mathbf{P h}$ & $\mathbf{P r} \mathbf{n}-\mathbf{C}_{\mathbf{1 7}}$ & $\mathbf{P h} / \mathbf{n}-\mathbf{C}_{\mathbf{1 8}}$ & $\mathbf{C}_{\mathbf{2 7}}(\mathbf{\%})$ & $\mathbf{C}_{\mathbf{2 8}}(\boldsymbol{\%})$ & $\mathbf{C}_{\mathbf{2 9}}(\mathbf{\%})$ \\
\hline KK-1 & 1.55 & 0.48 & 0.34 & 38.57 & 25.68 & 35.75 \\
KK-2 & 1.29 & 0.58 & 0.16 & 37.95 & 30.86 & 31.19 \\
KK-3 & 0.94 & 0.57 & 0.17 & 37.89 & 18.68 & 43.43 \\
KK-4 & 0.32 & 0.25 & 0.31 & 28.13 & 27.74 & 44.13 \\
KK-5 & 0.38 & 0.23 & 0.20 & 33.03 & 29.50 & 37.47 \\
KK-6 & 0.47 & 0.21 & 0.32 & 30.61 & 27.15 & 42.24 \\
ND-1 & 0.84 & 0.22 & 0.13 & 55.40 & 17.93 & 26.67 \\
ND-2 & 1.20 & 0.32 & 0.14 & 53.29 & 14.21 & 32.50 \\
ND-3 & 1.58 & 0.38 & 0.14 & 51.85 & 21.95 & 26.20 \\
ND-4 & 1.04 & 0.14 & 0.14 & 54.36 & 18.46 & 27.18 \\
ND-5 & 0.96 & 0.06 & 0.04 & 53.68 & 18.69 & 27.62 \\
ND-6 & 1.22 & 0.15 & 0.09 & 48.87 & 18.80 & 32.33 \\
\hline KK average & 0.83 & 0.39 & 0.25 & 34.36 & 26.60 & 39.04 \\
\hline ND average & 1.14 & 0.22 & 0.12 & 52.91 & 18.34 & 28.75 \\
\hline
\end{tabular}

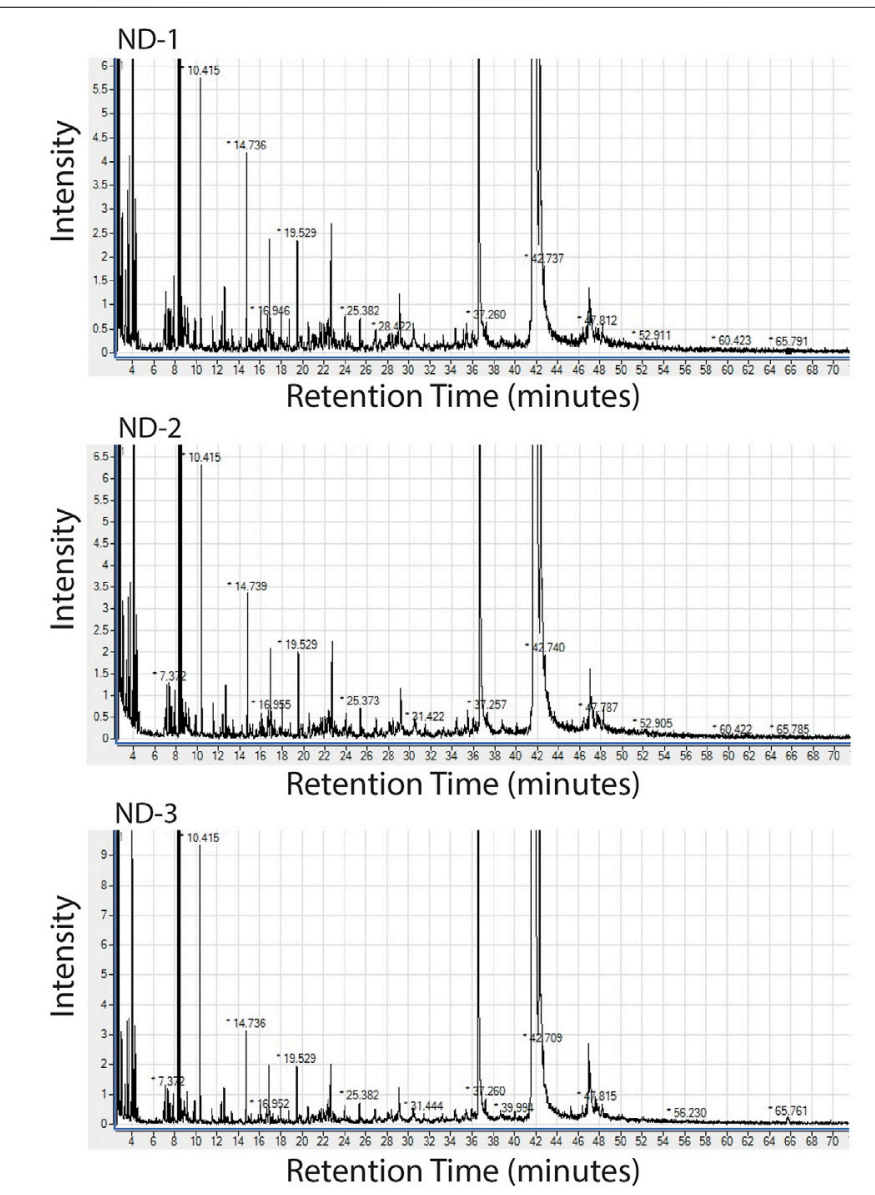

organic materials are derived from different sources. A predominance of medium to long molecular weight compounds $\left(\mathrm{nC}_{20}-\mathrm{nC}_{30}\right)$ in the Khao Khwang samples suggest a mixed contribution from terrigenous and marine organic matter (Figure 5A). Nam Duk samples exhibit a predominance of short molecular weight compounds $\left(\mathrm{nC}_{15}-\mathrm{nC}_{18}\right)$ suggesting marine organism inputs (Figure 5B; Tissot et al., 1978). $\mathrm{Pr} / \mathrm{Ph}$ ratios (less than 3) also confirm that samples from both Formations were deposited in a marine environment (Table 1).

\subsubsection{Pristane $(\mathrm{Pr}) / \mathrm{n}-\mathrm{C}_{17}$ and Phytane $(\mathrm{Ph}) / \mathrm{n}-\mathrm{C}_{18}$}

A cross-plot diagram between $\mathrm{Pr} / \mathrm{n}-\mathrm{C}_{17}$ and $\mathrm{Ph} / \mathrm{n}-\mathrm{C}_{18}$ shows that the Khao Khwang and Nam Duk samples are dominated by a combination of terrigenous kerogen type III and marine kerogen type II (Figure 6). These plots also suggest both Formations were deposited in sub-oxic to oxic condition and that the Nam Duk samples are more mature than the Khao Khwang samples. Pristane and phytane concentrations of both Formations are typically lower
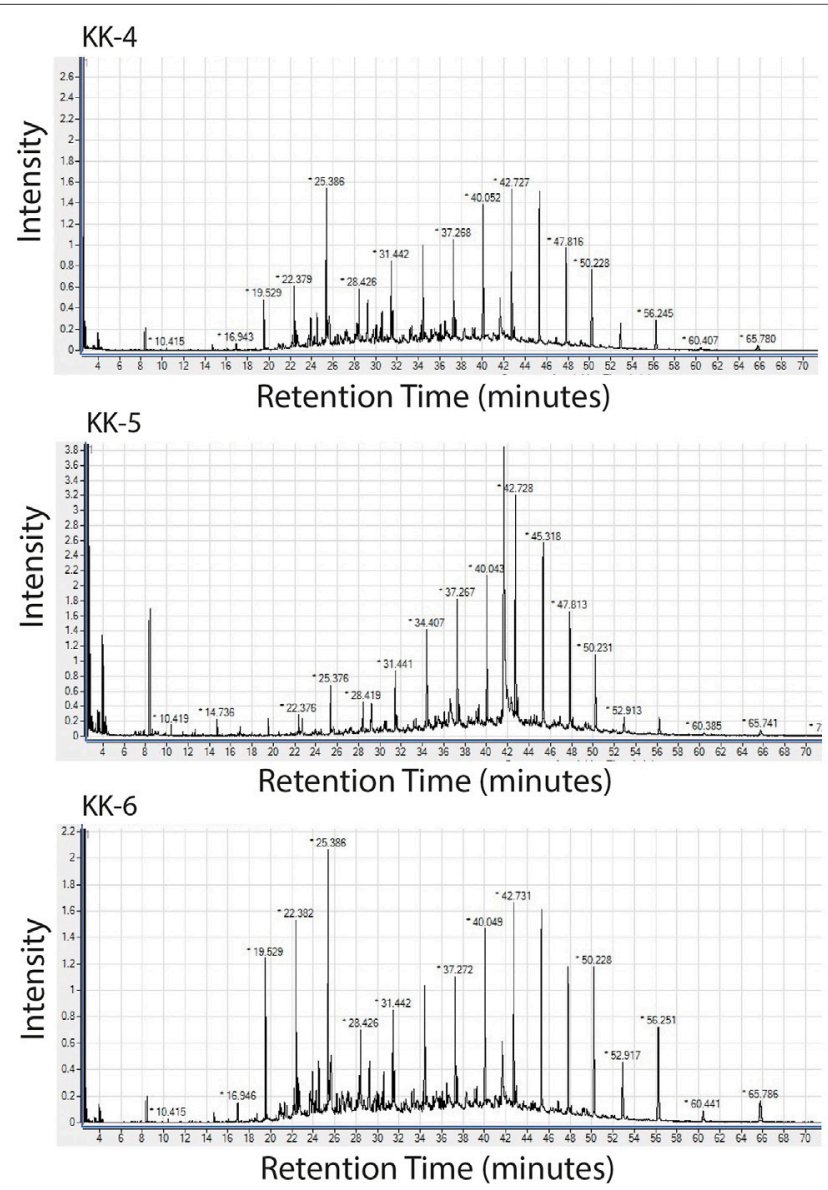

FIGURE 5 | The examples of mass chromatograms showing n-alkane distributions for (A) the Khao Khwang Formation (KK-4, KK-5, KK-6) and (B) the Nam DuK Formation (ND-1, ND-2, ND-3). 


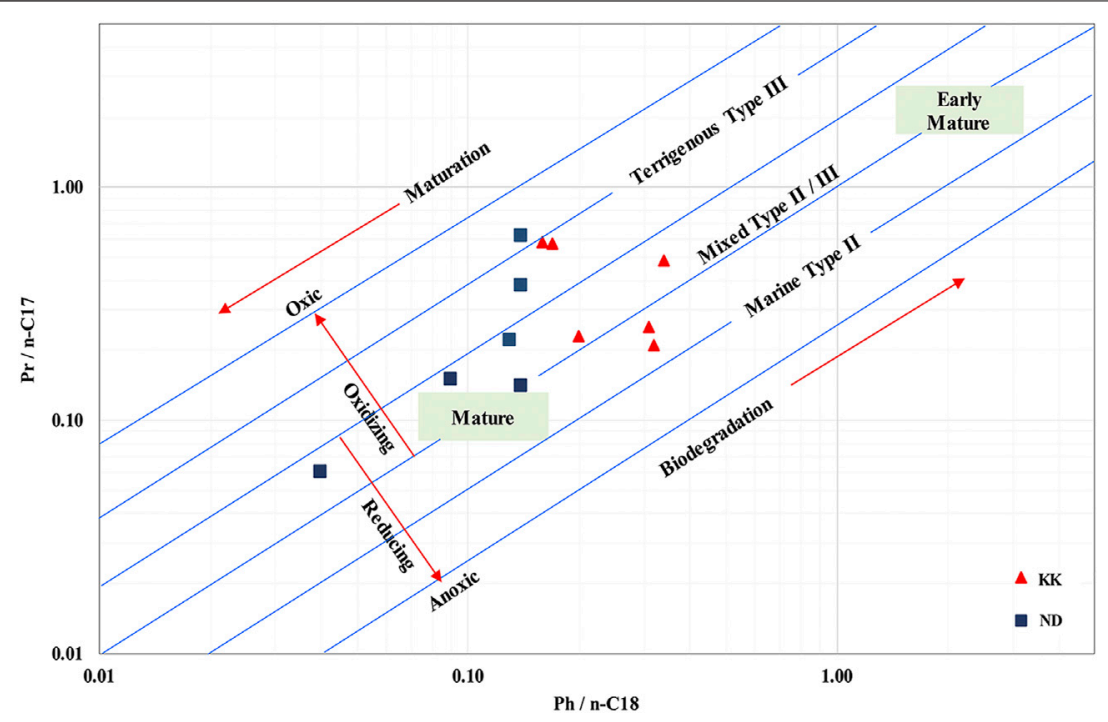

FIGURE 6 | Plot of pristane/n- $\mathrm{C}_{17}\left(\mathrm{Pr} / \mathrm{n}-\mathrm{C}_{17}\right)$ versus phytane/n- $\mathrm{C}_{18}\left(\mathrm{Ph} / \mathrm{n}-\mathrm{C}_{18}\right)$ for the Khao Khwang (KK) and Nam Duk (ND) Formations.

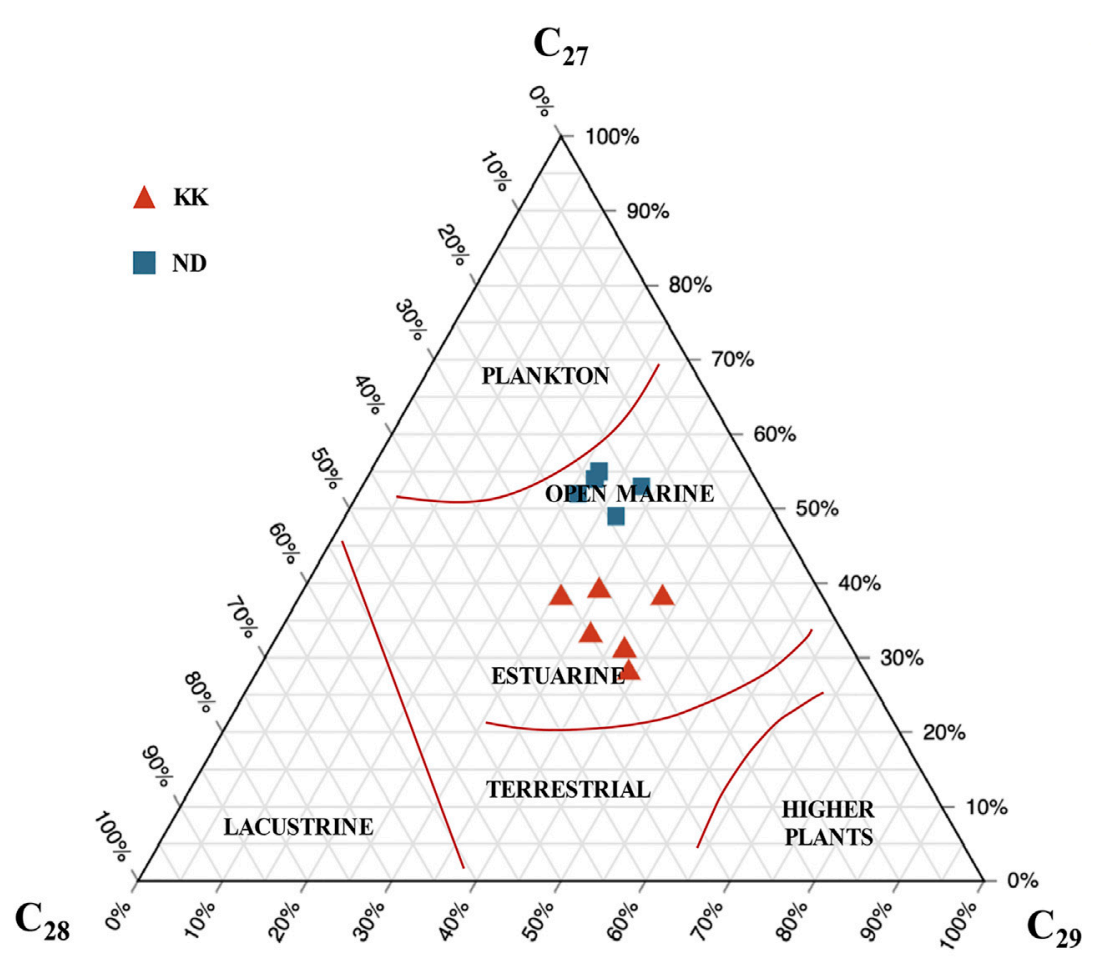

FIGURE 7 | Ternary diagram of relative abundance of $\mathrm{C}_{27}, \mathrm{C}_{28}$ and $\mathrm{C}_{29}$ regular steranes shows organic matter source and depositional environment of the samples from the Khao Khwang (KK) and Nam Duk (ND) Formations.

than $\mathrm{n}-\mathrm{C}_{17}$ and $\mathrm{n}-\mathrm{C}_{18}$, respectively. The $\mathrm{Pr} / \mathrm{n}-\mathrm{C}_{17}$ ratios of the Khao Khwang samples range from 0.2 to 0.6 , and from 0.1 to 0.9 for the Nam Duk samples (Table 1). Additionally, the $\mathrm{Ph} / \mathrm{n}-\mathrm{C}_{18}$ ratios of the Khao Khwang samples range from 0.2 to 0.3 , and from 0.04 to 0.1 for the Nam Duk samples (Table 1).

\subsubsection{Steranes and Terpanes}

The relative abundance of $\mathrm{C}_{27}, \mathrm{C}_{28}$ and $\mathrm{C}_{29}$ steranes from this study was converted to a percentage and plotted in a ternary diagram (Table 1; Figure 7). The average abundances of $\mathrm{C}_{27}, \mathrm{C}_{28}$ and $\mathrm{C}_{29}$ regular steranes of the Khao Khwang samples are 34.36, 
TABLE 2 The carbon and oxygen isotope compositions of the fibrous calcite vein and host rock matrix of the Khao Khwang (KK-5) and Nam Duk (ND-1) samples.

\begin{tabular}{|c|c|c|c|c|c|}
\hline \multirow[t]{2}{*}{ Sample } & $\begin{array}{c}\delta^{18} \text { O PDB } \\
(\%)\end{array}$ & $\begin{array}{c}\delta^{13} \text { C PDB } \\
(\%)\end{array}$ & \multirow[t]{2}{*}{ Sample } & $\begin{array}{c}\delta^{18} \text { O PDB } \\
(\%)\end{array}$ & $\begin{array}{c}\delta^{13} C \text { PDB } \\
(\% \circ)\end{array}$ \\
\hline & \multicolumn{2}{|c|}{ KK-5 } & & \multicolumn{2}{|c|}{ ND-1 } \\
\hline Vein & -10.65 & 2.87 & Vein & -12.42 & 3.75 \\
\hline Vein & -11.09 & 2.77 & Vein & -11.45 & 4.15 \\
\hline Vein & -10.36 & 2.96 & Vein & -11.19 & 4.36 \\
\hline Vein & -10.56 & 2.97 & Vein & -11.91 & 3.13 \\
\hline Vein & -10.67 & 2.96 & Matrix & -12.53 & 2.69 \\
\hline Matrix & -10.20 & 2.69 & Matrix & -13.79 & 2.20 \\
\hline Matrix & -10.38 & 2.78 & Matrix & -13.49 & 2.45 \\
\hline Matrix & -10.48 & 2.70 & Matrix & -14.03 & 2.04 \\
\hline Matrix & -11.83 & 2.20 & Matrix & -13.34 & 2.23 \\
\hline Matrix & -10.06 & 2.50 & Matrix & -14.27 & 1.67 \\
\hline Vein & -9.98 & 3.01 & Matrix & -13.64 & 2.12 \\
\hline Vein & -9.96 & 3.15 & Matrix & -14.02 & 2.16 \\
\hline \multirow[t]{3}{*}{ Vein } & -11.14 & 2.82 & Matrix & -13.85 & 2.26 \\
\hline & & & Matrix & -14.10 & 2.14 \\
\hline & & & Matrix & -14.88 & 1.95 \\
\hline Avg. total & -10.57 & 2.80 & & -13.26 & 2.62 \\
\hline Avg. vein & -10.55 & 2.94 & & -11.74 & 3.85 \\
\hline Avg. matrix & -10.59 & 2.57 & & -13.81 & 2.17 \\
\hline
\end{tabular}

26.60 and 39.04\%; and 52.91, 18.34 and 28.75\% for the Nam Duk samples (Table 1). The regular steranes suggest that the organic matter came from a marine environment with elevated $\mathrm{C}_{27}$ and $\mathrm{C}_{29}$, and were deposited in estuarine (or shallow marine) to open marine settings. This interpretation is also supported by $\operatorname{Pr} / n-C_{17}$ and $\mathrm{Ph} / \mathrm{n}-\mathrm{C}_{18}$ ratios (Figure 6).

\subsection{Carbon and Oxygen Stable Isotopes}

The results of stable carbon and oxygen isotope analyses of the samples from both Formations are summarized in Table 2 and plotted in Figure 8. The $\delta^{18} \mathrm{O}$ values of the fibrous calcite veins and host rock matrices of the Nam Duk samples are more depleted than the Khao Khwang samples. The fibrous calcite veins from the Nam Duk samples also show higher values of $\delta^{13} \mathrm{C}$ compared to the Khao Khwang samples, indicating overall heavier carbon isotope compositions. The carbon and oxygen isotope compositions of the Khao Khwang and Nam Duk samples are plotted along with the sample profile in Figure 9 and Figure 10, respectively. The carbon and oxygen isotope compositions of the fibrous calcite veins are generally quite similar to those in the host rock matrix, especially within the Khao Khwang samples (Figures 9, 10). The carbon isotope compositions of the fibrous calcite vein are slightly more elevated than in the host rock matrix, presumably reflecting incorporation of organic carbon into vein cement.

\subsubsection{Khao Khwang Formation}

The $\delta^{13} \mathrm{C}$ values of the fibrous calcite veins range from +2.77 to $+3.15 \%$ with an average value of $+2.94 \%$. The $\delta^{13} \mathrm{C}$ values of the host rock matrix ranges from +2.20 to $+2.78 \%$ with an average value of $+2.57 \%$. The $\delta^{18} \mathrm{O}$ values of the fibrous calcite veins range from -9.96 to $-11.09 \%$ with an average value of $-10.55 \%$ and between -10.06 and $-11.83 \%$ in the matrix with an average value of $-10.59 \%$. Accordingly, the $\delta^{13} \mathrm{C}$ and $\delta^{18} \mathrm{O}$ values of the fibrous calcite are slightly different from the matrix.

\subsubsection{Nam Duk Formation}

The $\delta^{13} \mathrm{C}$ values of the fibrous calcite vein range from +3.13 to $+4.36 \%$ with an average value of $+3.85 \%$. In the host rock matrix, the $\delta^{13} \mathrm{C}$ values range from +1.67 to $+2.69 \%$ with an average value of $+2.17 \%$. The $\delta^{18} \mathrm{O}$ values of the fibrous calcite vein are between -11.19 and $-12.42 \%$ with an average value of $-11.74 \%$ and are between -12.53 and $-14.88 \%$ in the host rock matrix with an average value of $-13.26 \%$. The $\delta^{18} \mathrm{O}$ values from the host rock matrix are more depleted than from the fibrous

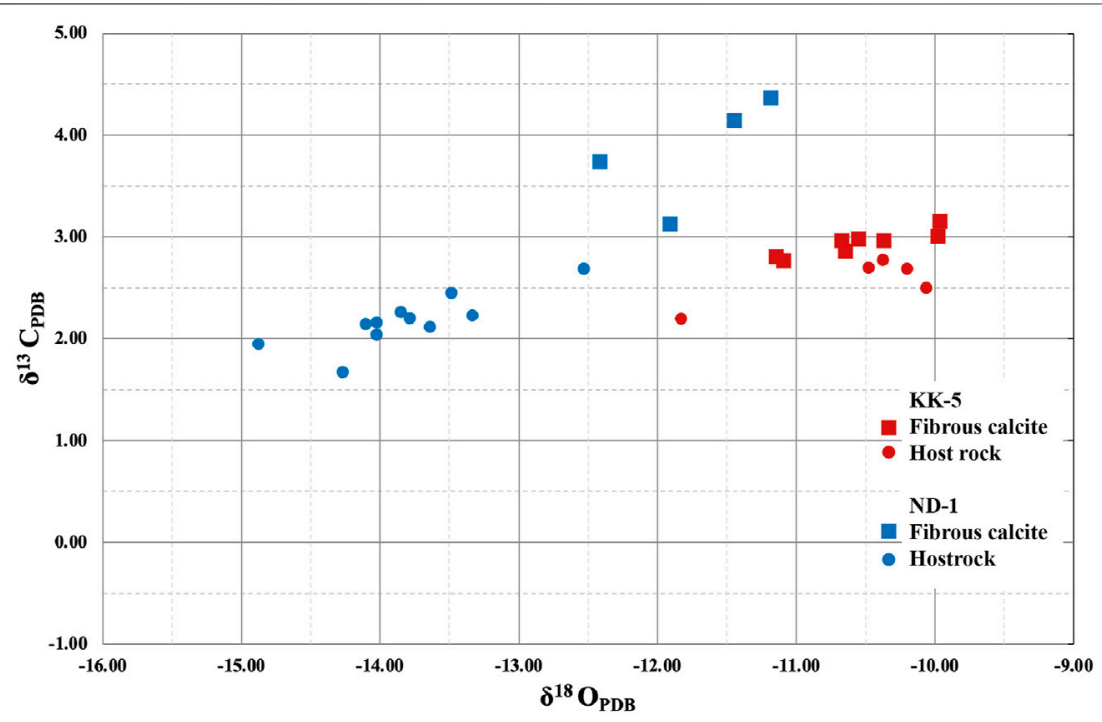

FIGURE 8 | Carbon and oxygen isotope compositions from the fibrous calcite vein and host rock of the Khao Khwang (KK-5) and Nam Duk (ND-1) samples. 

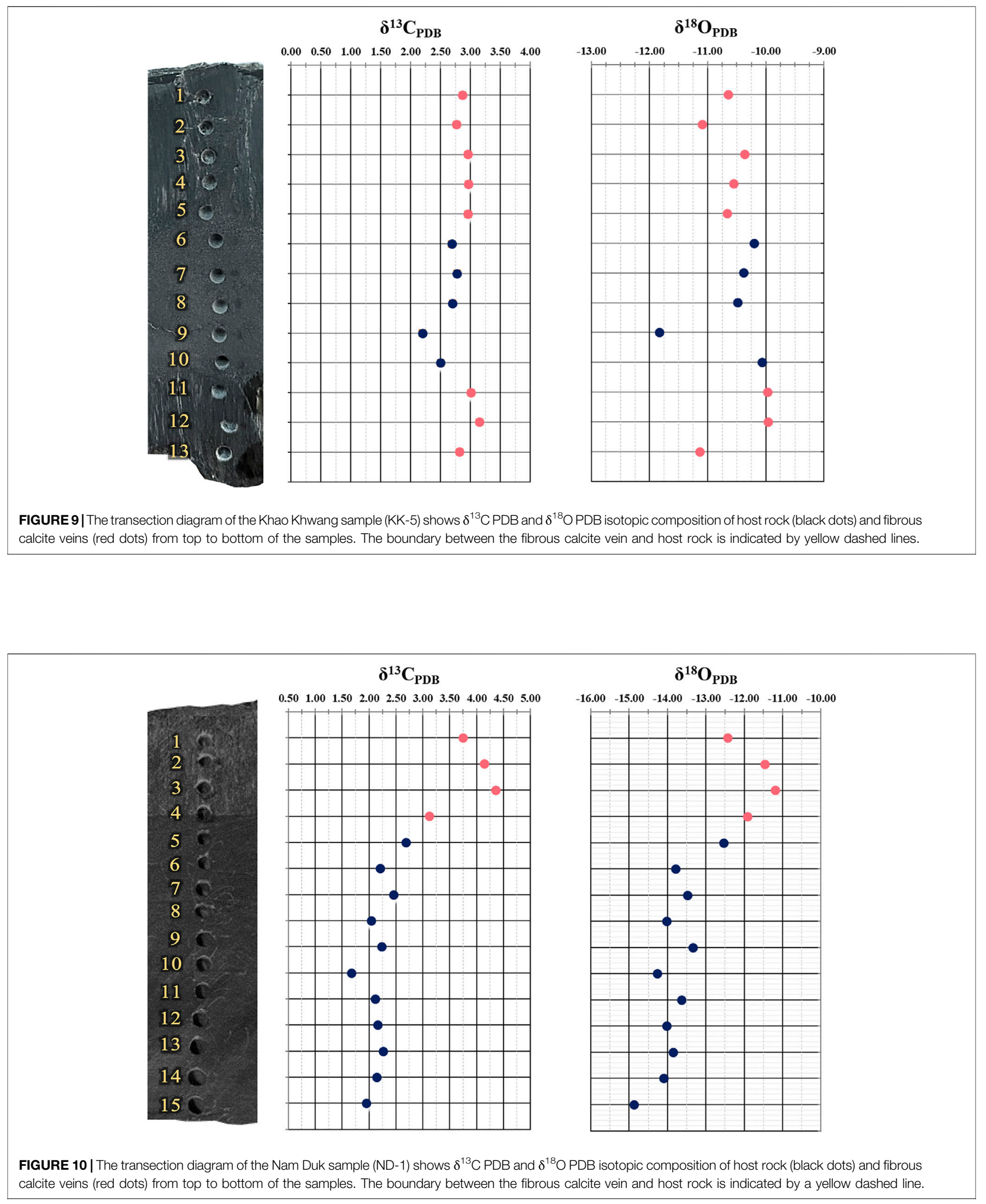
calcite veins. The $\delta^{13} \mathrm{C}$ values of the fibrous calcite veins are heavier than from the host rock matrix.

\section{DISCUSSION}

\subsection{Paleo-Depositional Environment}

Biomarker analysis of soluble organic matter (bitumen) from the rock samples hosting the fibrous calcite veins has contributed to a better understanding of the characteristics of the depositional environments (e.g., Waples and Machihara, 1991; Sivan et al., 2008). In this study, organic facies and depositional environment are interpreted using $\mathrm{Pr} / \mathrm{Ph}$ ratio, $\mathrm{Pr} / \mathrm{n}-\mathrm{C}_{17}$ and $\mathrm{Ph} / \mathrm{n}-\mathrm{C}_{18}$ cross plots and sterane distributions (e.g., Shanmugam, 1985). Samples from both Formations have similar isoprenoid, $n$-alkane and sterane distributions, and thus are similar in depositional environment, organic matter type and maturity (Figures 5-7; Table 1). Molecular geochemical data from both Formations suggest that the rock samples are deposited in a marine environment with a mixed source of organic matter from the marine and terrestrial. However, there are slight differences in likely paleo-geography and thermal maturation between the two Formations.

Based on these data, rock samples from the Khao Khwang Formation are believed to have been deposited in a lagoonal/ estuarine or shallow marine environment. In contrast, based on $n$-alkane and sterane distributions, the Nam Duk Formation was deposited in a somewhat deeper water slope environment. That is, a higher proportion of land plant material was deposited within the Khao Khwang Formation. These interpretations coincide with results from previous studies on depositional environments for both Formations (e.g., Chitnarin et al., 2008; Chenrai and Fuengfu, 2019). The same settings of the relevant organic facies are confirmed by the bivariate plot trends of the $\mathrm{Pr} /$ $\mathrm{Ph}$ ratio, the $\mathrm{Pr} / \mathrm{n}-\mathrm{C}_{17}$ and $\mathrm{Ph} / \mathrm{n}-\mathrm{C}_{18}$ cross plot and the tertiary diagram of regular steranes (Figure 7 ).

\subsection{Petroleum Potential Source Rock}

Total organic carbon (TOC) contents in the Khao Khwang Formation imply fair to excellent source rock potential (Racey, 2011; Chenrai and Fuengfu, 2019). Unfortunately, there is no similar data measure for the Nam Duk Formation. However, the $\mathrm{Pr} / \mathrm{n}-\mathrm{C}_{17}$ and $\mathrm{Ph} / \mathrm{n}-\mathrm{C}_{18}$ cross plot reveals that the samples from both Formations contain a mixed kerogen, between type III and type II, deposited under sub-oxic to oxic conditions. It should be noted that these analyzed data are from outcrop samples that may be somewhat oxidized, tied to exposure to the more oxic conditions near the present-day landsurface. If organic matter was first deposited in anoxic to sub-oxic conditions, the rock samples would be considered potential oil and gas sources for both Formations. Abundant framboidal pyrites having a various size from $5.7 \mu \mathrm{m}$ to $0.5 \mathrm{~mm}$ within the rock samples, especially from the Khao Khwang Formation, also suggest that the samples were deposited under relatively anoxic conditions (Wilkin et al., 1996; Liu et al., 2019). The Nam Duk Formation was likely deposited further from a terrestrial organic matter source than the Khao Khwang Formation, based on $n$-alkane and sterane distributions. This implies fine-grained rocks in the Khao Khwang Formation have a higher petroleum potential than the Nam Duk Formation. Thermal maturation of the Nam Duk Formation is interpreted to be higher than the Khao Khwang Formation, based on the $\mathrm{Pr} / \mathrm{n}-\mathrm{C}_{17}$ and $\mathrm{Ph} / \mathrm{n}-\mathrm{C}_{18}$ cross plot (Figure 6). This higher thermal maturation interpretation is supported by the $\delta^{18} \mathrm{O}$ values of the Khao Khwang samples being more negative than the Nam Duk samples (Figure 8), indicating that the calcites within the Khao Khwang samples were precipitated at somewhat higher temperatures (Al-Aasm et al., 1993).

\subsection{Fibrous Calcite Development}

Bedding-parallel calcite veins are widely documented, as are interpretations of the formative mechanisms driving aligned fibrous crystal growth within sedimentary strata during burial diagenesis and compaction (Franks, 1969; Cobbold et al., 2013). Nam Duk samples are dominated by beef veins with a smooth continuous boundary between the fibrous calcites and host rock bedding surface. This probably indicates that the beef veins grew at a consistent rate. On the other hand, the Khao Khwang samples mostly fibrous calcite cone-in-cone veins, with abundant inclusions of host-mud. These samples likely grew under more fluctuating conditions, with times of rapid growth indicated by intervals enclosing more mud inclusions. The ability of the calcite to encase mud inclusions likely indicates that the host rock was also semi to unconsolidated at the time of calcite crystal growth. Beef veins without mud inclusions suggest a more brittle or consolidated host rock at the time of fibrous calcite precipitation (e.g., Meng et al., 2017). Hence, beef veins in the Nam Duk Formation likely formed during deeper burial diagenesis and in more compacted situations than cone-incone veins in the Khao Khwang Formation. Both the cone-incone and beef vein fabrics are a fibrous growth response to saturated conditions in a hydrologic regime derived from local carbonaceous fluids within the host rock. Individual crystal fibers grew vertically and inward during the periodic opening of the vein space.

Stable isotope compositions can be used to refine interpretations of growth style and relative timing of fibrous calcite development. Negative signatures in organic matter can provide evidence of an organic bicarbonate $\left(\mathrm{HCO}_{3}{ }^{-}\right)$sourced in zones of bacterial sulphate reduction in shallow-burial anaerobic environments (Irwin et al., 1977). The bicarbonate fixed in fibrous calcites precipitated in this zone usually inherit $\delta^{13} \mathrm{C}$ signatures from this organic matter; hence a much-depleted carbon isotope composition is expected to occur in calcites formed in this zone $\left(\delta^{13} \mathrm{C}<-25 \%\right.$ PDB; Irwin et al., 1977). After sulphate is totally consumed in the bacterial sulphate reduction zone, the microbial methanogenic zone is entered; there Archaeal methanogens can continue to be active until temperatures reach $\sim 75^{\circ} \mathrm{C}$ (the petroleum generation window; Morad, 2009).

Samples from the two Formations show positive $\delta^{13} \mathrm{C}$ values, suggesting that the heavy carbon in the formative bicarbonate was influenced by microbial activity in a methanogenic zone that underlay the bacterial sulphate reduction zone. There the carbon 
dioxide $\left(\mathrm{CO}_{2}\right)$ generated within the microbial methanogenic zone tends to have heavy carbon isotope compositions $\left(\delta^{13} \mathrm{C} \approx 0-15 \%\right.$ o PDB) via microbial fermentation (Raiswell, 1987; Wolff et al., 1992). Thus, if the buried organic-rich rocks still have organic matter remaining after passing through the bacterial sulphate reduction zone, they can generate carbon dioxide with $\delta^{13} \mathrm{C}$ enriched carbon. This leads to progressive ${ }^{13} \mathrm{C}$ enrichment in bicarbonate fixed as calcite forming within the rocks. Fibrous calcite veins in this zone are expected to be similar to the veins in the two Formations. Overall $\delta^{13} \mathrm{C}$ carbon composition will be positive if there is no subsequent external fluid intrusion, as is likely due to the ongoing low permeability of the host rocks (Luan, et al., 2019). Thus, moderate positive $\delta^{13} \mathrm{C}$ values from the Khao Khwang and Nam Duk Formations possibly suggest a carbon source from carbon dioxide influenced by microbial methanogenesis.

Oxygen isotope compositions of the fibrous calcite veins from both Formations are more depleted when compared to the range of Permian carbonate rock precipitation in equilibrium with Permian seawater as $-4.8 \%$ PDB (Veizer et al., 1999). The measured negative oxygen isotope signatures $(\approx-10$ to $-13 \%$ ) are too negative and likely reflect ongoing local rock-buffered rock-fluid interactions, carbonate precipitation and reequilibration is occurring in modified marine pore waters within adiagenetic systems at somewhat deeper burial depths where the temperature are progressively increasing (Hodgson, 1966; Dickson and Coleman, 1980; Marshall, 1982; Nuriel, et al., 2011; Uysal, et al., 2011; Warren et al., 2014).

\section{CONCLUSION}

The bedding-parallel fibrous calcite veins from the Khao Khwang and Nam Duk Formations are divided into two types; beef and cone-in-cone veins. Their carbon and oxygen isotope compositions suggest that the calcite veins were precipitated from a carbon source by carbon dioxide generated in the zone of microbial methanogenesis, giving $\delta^{13} \mathrm{C}$-enriched carbon isotope compositions. Thus, the fibrous calcite veins of the two Formations exhibit moderate positive $\delta^{13} \mathrm{C}$ values at the present day. Their $\delta^{18} \mathrm{O}$-depleted isotope compositions indicated that the fibrous calcite veins re-equilibrated in locally-derived warmer fluids (no external carbon source) likely tied to somewhat deeper burial. The fibrous calcite veins are interpreted to be

\section{REFERENCES}

Al-Aasm, I. S., Muir, I., and Morad, S. (1993). Diagenetic Conditions of Fibrous Calcite Vein Formation Black Shales: Petrographic, Chemical and Isotopic Evidence. Bull. B. Can. Petrol. Geol. 41, 46-56. doi:10.35767/gscpgbull.41.1.046

Al-Khafaji, A. J., Hakimi, M. H., Mohialdeen, I. M. J., Idan, R. M., Afifyf, W. E., and Lashin, A. (2020). Geochemical Characteristics of Crude Oils and basin Modelling of the Probable Source Rocks in the Southern Mesopotamian Basin, South Iraq. J. Petrol. Sci. Eng. 196, 107641. doi:10.1016/ j.petrol.2020.107641

Allegre, C. J., and Sutcliffe, C. (2008). Isotope Geology. Cambridge: Cambridge University Press. doi:10.1017/CBO9780511809323 precipitated in the surrounding semi-consolidated sediments, and so calcite crystals are preserved as cone-in-cone veins with abundant host-mud inclusions. Beef veins that typify the Nam Duk Formation are believed to have precipitated in more consolidated fine-grained sediment hosts in the somewhat deeper burial zone compared to the Khao Khwang Formation.

Our petroleum assessment of the Khao Khwang and Nam Duk Formations suggests that both Formation are a petroleum potential source rock with type II/III kerogen. The depositional environment of organic matter in the Khao Khwang Formation was either an estuarine environment or a shallow marine environment. Organic signatures in the Nam Duk Formation suggest a somewhat deeper water slope-tobasin marine setting or an open marine environment. Thus, results in this study provide a better understanding between the bedding-parallel fibrous calcite veins and petroleum source rock potential in a sedimentary basin using analytical approaches that could also be applied for petroleum exploration in a frontier area.

\section{DATA AVAILABILITY STATEMENT}

The original contributions presented in the study are included in the article/supplementary material, further inquiries can be directed to the corresponding author.

\section{AUTHOR CONTRIBUTIONS}

PC and TA: Conceptualization, field collection, methodology, formal analysis, investigation, writing manuscript; JW: review and editing manuscript; SS: field collection, laboratory investigation, preparing manuscript; SM: petrography investigation; IC: isotope analysis.

\section{ACKNOWLEDGMENTS}

The authors gratefully acknowledge the financial support from the Ratchadaphisek Somphot Endowment Fund under Outstanding Research Performance Program, Chulalongkorn University (Sci-Super VII_64_002). Reviewers are thanked for their useful and constructive comments.

Amane, W., and Hideki, N. (1997). Geochemical Characteristics of Terrigenous and marine Sourced Oils in Hokkaido, Japan. Org. Geochem. 28, 27-41. doi:10.1016/s0146-6380(97)00102-2

Booth, J., and Sattayarak, N. (2011). "Subsurface Carboniferous-Cretaceous Geology of NE Thailand," in The Geology of Thailand. Editors M. F. Ridd, A. J. Barber, and M. J. Crow (London: The Geological Society), 185-222.

Bunopas, S. (1983). "Palaeozoic Succession in Thailand," in Proceedings of the Workshop on Stratigraphic Correlation of Thailand and Malaysia 1983 Conference, Haad Yai, Thailand, 39-76.

Cabral, F. A. A., Silveira, A. C., Ramos, G. M. S., Miranda, T. S., Barbosa, J. A., and Neumann, V. H. M. L. (2019). Microfacies and Diagenetic Evolution of the Limestones of the Upper Part of the Crato Formation, Araripe Basin, 
Northeastern Brazil. Braz. J. Geol. 49 (1), e20180097. doi:10.1590/23174889201920180097

Chandra, K., Mishra, C. S., Samanta, U., Gupta, A., and Mehrotra, K. L. (1994). Correlation of Different Maturity Parameters in the Ahmedabad-Mehsana Block of the Cambay basin. Org. Geochem. 21 (3-4), 313-321. doi:10.1016/ 0146-6380(94)90193-7

Chenrai, P., and Fuengfu, S. (2019). Organic Geochemistry of the Lower Permian Tak Fa Formation in Phetchabun Province, Thailand: Implications for its Paleoenvironment and Hydrocarbon Generation Potential. Acta Geochim. 39 (3), 291-306. doi:10.1007/s11631-019-00370-w

Chitnarin, A., Crasquin, S., Charoentitirat, T., Tepnarong, P., and Thanee, N. (2012). Ostracods (Crustacea) of the Early-Middle Permian from Central thailand (Indochina Block). Part I. Order Palaeocopida. Geodiversitas 34, 801-835. doi:10.5252/g2012n4a5

Chitnarin, A., Crasquin, S., Chonglakmani, C., Broutin, J., Grote, P. J., and Thanee, N. (2008). Middle Permian Ostracods from Tak Fa Limestone, Phetchabun Province, Central Thailand. Geobios 41, 341-353. doi:10.1016/ j.geobios.2007.09.001

Chonglakmani, C. (2005). Paleogeography of the Permian System in the SaraburiNakhon Ratchasima area (in Thai). Thailand: Suranaree University of Technology.

Chonglakmani, C., and Helmcke, D. (2001). Geodynamic Evolution of Loei and Phetchabun Regions - Does the Discovery of Detrital Chromian Spinels from the Nam Duk Formation (Permian, North-Central Thailand) Provide New Constraint? Gondwana Res. 4, 437-442. doi:10.1016/s1342-937x(05)70343-9

Chonglakmani, C., and Sattayarak, N. (1984). Geological Map of Thailand on 1: 250,000 Scale: Sheet Changwat Phetchabun (NE47-16). Bangkok, Thailand: Department of Mineral Resources.

Cobbold, P. R., and Rodrigues, N. (2007). Seepage Forces, Important Factors in the Formation of Horizontal Hydraulic Fractures and Bedding-Parallel Fibrous Veins ('beef' and 'Cone-in-Cone'). Geofluids 7, 313-322. doi:10.1111/j.14688123.2007.00183.x

Cobbold, P. R., Zanella, A., Rodrigues, N., and Løseth, H. (2013). Bedding-parallel Fibrous Veins ('Beef and 'Cone-in-Cone'): Worldwide Occurrence and Possible Significance in Terms of Fluid Overpressure, Hydrocarbon Generation and Mineralization. Mar. Pet. Geology. 43, 1-20. doi:10.1016/ j.marpetgeo.2013.01.010

Demény, A., Kele, S., and Siklósy, Z. (2010). Empirical Equations for the Temperature Dependence of Calcite-Water Oxygen Isotope Fractionation from 10 to $70^{\circ} \mathrm{C}$. Rapid Commun. Mass. Spectrom. 24 (24), 3521-3526. doi: $10.1002 / \mathrm{rcm} .4799$

Dickson, J. A. D., and Coleman, M. L. (1980). Changes in Carbon and Oxygen Isotope Composition during limestone Diagenesis. Sedimentology 27, 107-118. doi:10.1111/j.1365-3091.1980.tb01161.x

Franks, P. C. (1969). Nature, Origin, and Significance of Cone-in-Cone Structures in the Kiowa Formation (Early Cretaceous), North-Central Kansas. J. Sediment. Res. 39, 1483-1454. doi:10.1306/74d71e51-2b21$11 \mathrm{~d} 7-8648000102 \mathrm{c} 1865 \mathrm{~d}$

Greene, S. E., Bottjer, D. J., Corsetti, F. A., Berelson, W. M., and Zonneveld, J.-P. (2012). A Subseafloor Carbonate Factory across the Triassic-Jurassic Transition. Geology 40 (11), 1043-1046. doi:10.1130/g33205.1

Heindel, K., Richoz, S., Birgel, D., Brandner, R., Klügel, A., Krystyn, L., et al. (2015). Biogeochemical Formation of Calyx-Shaped Carbonate crystal Fans in the Subsurface of the Early Triassic Seafloor. Gondwana Res. 27 (2), 840-861. doi:10.1016/j.gr.2013.11.004

Helmcke, D., and Kraikhong, C. (1982). On the Geosynclinals and Orogenic Evolution of Central and Northeastern Thailand. J. Geol. Soc. 5, 47-52.

Hodgson, W. A. (1966). Carbon and Oxygen Isotope Ratios in Diagenetic Carbonates from marine Sediments. Geochim. Cosmochim. Acta 30, 1223-1233. doi:10.1016/0016-7037(66)90121-9

Hooker, J. N., Abu-Mahfouz, I. S., Meng, Q., and Cartwright, J. (2019). Fractures in Mudrocks: Advances in Constraining Timing and Understanding Mechanisms. J. Struct. Geol. 125, 166-173. doi:10.1016/j.jsg.2018.04.020

Huang, W.-Y., and Meinschein, W. G. (1979). Sterols as Ecological Indicators. Geochim. Cosmochim. Acta 43, 739-745. doi:10.1016/0016-7037(79)90257-6

Hughes, W. B., Holba, A. G., and Dzou, L. I. P. (1995). The Ratios of Dibenzothiophene to Phenanthrene and Pristane to Phytane as Indicators of
Depositional Environment and Lithology of Petroleum Source Rocks. Geochim. Cosmochim. Acta 59, 3581-3598. doi:10.1016/0016-7037(95)00225-o

Irwin, H., Curtis, C., and Coleman, M. (1977). Isotopic Evidence for Source of Diagenetic Carbonates Formed during Burial of Organic-Rich Sediments. Nature 269 (5625), 209-213. doi:10.1038/269209a0

Kershaw, S., and Guo, L. (2016). Beef and Cone-in-Cone Calcite Fibrous Cements Associated with the End-Permian and End-Triassic Mass Extinctions: Reassessment of Processes of Formation. J. Palaeogeogr. 5, 28-42. doi:10.1016/j.jop.2015.11.003

Kozar, M. G., Crandall, G. F., and Hall, S. E. (1992). "Integrated Structural and Stratigraphic Study of the Khorat Basin, Rat Buri Limestone (Permian), Thailand," in Proceedings of National Conference on Geological Resources of Thailand, Potential for Future Development, Bangkok: Thailand (Bangkok, Thailand: Department of Mineral Resources), 682-736.

Landais, P. (1996). Petroleum Geochemistry and Geology. New York: American Chemical Society, 743.

Large, D. J., and Gize, A. P. (1996). Pristane/phytane Ratios in the Mineralized Kupferschiefer of the Fore-Sudetic Monocline, Southwest Poland. Ore Geol. Rev. 11, 89-103. doi:10.1016/0169-1368(95)00017-8

Lijmbach, W. M. (1975). "SP (1) on the Origin of Petroleum," in Proceedings of the 9th World Petroleum Congress, Tokyo, Japan, May 11-16, 1975.

Liu, Z., Chen, D., Zhang, J., Lü, X., Wang, Z., Liao, W., et al. (2019). Pyrite Morphology as an Indicator of Paleoredox Conditions and Shale Gas Content of the Longmaxi and Wufeng Shales in the Middle Yangtze Area, South China. Minerals 9 (7), 428. doi:10.3390/min9070428

Luan, G., Dong, C., Azmy, K., Lin, C., Ma, C., Ren, L., et al. (2019). Origin of Bedding-Parallel Fibrous Calcite Veins in Lacustrine Black Shale: a Case Study from Dongying Depression, Bohai Bay Basin. Mar. Pet. Geol. 102, 873-885. doi:10.1016/j.marpetgeo.2019.01.010

Ma, C., Dong, C., Luan, G., Lin, C., Liu, X., and Elsworth, D. (2016). Types, Characteristics and Effects of Natural Fluid Pressure Fractures in Shale: A Case Study of the Paleogene Strata in Eastern China. Pet. Exploration Dev. 43 (4), 634-643. doi:10.1016/s1876-3804(16)30074-x

Marshall, J. D. (1982). Isotopic Composition of Displacive Fibrous Calcite Veins: Reversals in Pore Water Composition Trends during Burial Diagenesis. J. Sediment. Res. 52, 615-630. doi:10.1306/212f7fb3-2b24-11d7$8648000102 \mathrm{c} 1865 \mathrm{~d}$

Meng, Q., Hooker, J., and Cartwright, J. (2017). Early Overpressuring in OrganicRich Shales during Burial: Evidence from Fibrous Calcite Veins in the Lower Jurassic Shales-With-Beef Member in the Wessex Basin, UK. J. Geol. Soc. 174, 869-882. doi:10.1144/jgs2016-146

Metcalfe, I., and Sone, M. (2008). Biostratigraphy and Palaeobiogeography of Lower Permian (Lower Kungurian) Conodonts from the Tak Fa Formation (Saraburi Limestone), Thailand. Palaeogeogr. Palaeoclimatol. Palaeoecol. 257 (1-2), 139-151. doi:10.1016/j.palaeo.2007.09.014

Miles, J. A. (1989). Illustrated Glossary of Petroleum Geochemistry. Oxford: Oxford University.

Moldowan, J. M., Seifert, W. K., and Gallegos, E. J. (1985). Relationship between Petroleum Composition and Depositional Environment of Petroleum Source Rocks. AAPG Bull. 69, 1255-1268. doi:10.1306/ad462bc8-16f7-11d7$8645000102 \mathrm{c} 1865 \mathrm{~d}$

Morad, S. (2009). "Carbonate Cementation in Sandstones: Distribution Patterns and Geochemical Evolution," in Carbonate Cementation in Sandstones. Editors S. Morad (John Wiley \& Sons), 1-26. doi:10.1002/9781444304893.ch1

Morley, C. K., Ampaiwan, P., Thanudamrong, S., Kuenphan, N., and Warren, J. (2013). Development of the Khao Khwang Fold and Thrust Belt: Implications for the Geodynamic Setting of Thailand and Cambodia during the Indosinian Orogeny. J. Asian Earth Sci. 62, 705-719. doi:10.1016/j.jseaes.2012.11.021

Moustafa, Y. M., and Morsi, R. E. (2012). "Biomarkers," in Chromatography and its Applications. Editor S. Dhanarasu (Croatia: Intech), 165-186.

Nakornsri, N. (1981). Geology and Mineral Resources of Amphoe Ban Mi (ND 474). Bangkok, Thailand: Department of Mineral Resources.

Nuriel, P., Rosenbaum, G., Uysal, T. I., Zhao, J., Golding, S. D., Weinberger, R., et al. (2011). Formation of Fault-Related Calcite Precipitates and Their Implications for Dating Fault Activity in the East Anatolian and Dead Sea Fault Zones. Geol. Soc. Lond. Spec. Publications 359 (1), 229-248. doi:10.1144/ sp359.13 
Osborne, M. J., and Swarbrick, R. E. (1997). Mechanism for Generative Overpressure in Sedimentary basin: a Reevalution. AAPG Bull. 81, 1023-1041. doi:10.1306/522B49C9-1727-11

Peters, K. E., and Moldowan, J. M. (1993). The Biomarker Guide: Interpreting Molecular Fossils in Petroleum and Ancient Sediments. Englewood Cliff: Pentice Hall.

Peters, K. E., Walters, C. C., and Moldowan, J. M. (2005). The Biomarker Guide. Cambridge: Cambridge University Press, 471.

Powell, T. G. (1988). Pristane/phytane Ratio as Environmental Indicator. Nature 333, 604. doi:10.1038/333604a0

Racey, A. (2011). "Petroleum Geology," in The Geology of Thailand. Editors M. F. Ridd, A. J. Barber, and M. J. Crow (London: The Geological Society), 351-392.

Raiswell, R. (1987). Non-steady State Microbiological Diagenesis and the Origin of Concretions and Nodular Limestones. Geol. Soc. Lond. Spec. Publications 36 (1), 41-54. doi:10.1144/gsl.sp.1987.036.01.05

Ridd, M. F., Barber, A. J., and Crow, M. J. (2011). The Geology of Thailand. London: The Geological Society. doi.org/doi:10.1144/GOTH

Rodrigues, N., Cobbold, P. R., Loseth, H., and Ruffet, G. (2009). Widespread Bedding-Parallel Veins of Fibrous Calcite ('beef') in a Mature Source Rock (Vaca Muerta Fm, Neuquén Basin, Argentina): Evidence for Overpressure and Horizontal Compression. J. Geol. Soc. 166, 695-709. doi:10.1144/001676492008-111

Shanmugam, G. (1985). Significance of Coniferous Rain Forests and Related Organic Matter in Generating Commercial Quantities of Oil, Gippsland Basin, Australia. AAPG Bull. 69, 1241-1254. doi:10.1306/ad462bc3-16f7$11 \mathrm{~d} 7-8645000102 \mathrm{c} 1865 \mathrm{~d}$

Simms, M. J. (2004). The Wessex Basin (Dorset and Central Somerset). Geol. Conservation Rev. Ser. 30, 53-107. doi:10.1016/j.jhg.2004.07.003

Sivan, P., Datta, G. C., and Singh, R. R. (2008). Aromatic Biomarkers as Indicators of Source, Depositional Environment, Maturity and Secondary Migration in the Oils of Cambay Basin, India. Org. Geochem. 39, 1620-1630. doi:10.1016/ j.orggeochem.2008.06.009

Tissot, B., Deroo, G., and Hood, A. (1978). Geochemical Study of the Uinta Basin: Formation of Petroleum from the Green River Formation. Geochim. Cosmochim. Acta 42, 1469-1485. doi:10.1016/0016-7037(78)90018-2

Tribovillard, N., Petit, A., Quijada, M., Riboulleau, A., Sansjofre, P., Thomazo, C., et al. (2018). A Genetic Link Between Synsedimentary Tectonics-Expelled Fluids, Microbial Sulfate Reduction and Cone-in-Cone Structures. Mar. Pet. Geol. 93, 437-450. doi:10.1016/j.marpetgeo.2018.03.024

Udchachon, M., Burrett, C., Thassanapak, H., Chonglakmani, C., Campbell, H., and Feng, Q. (2014). Depositional Setting and Paleoenvironment of an AlatoconchidBearing Middle Permian Carbonate Ramp Sequence in the Indochina Terrane. J. Asian Earth Sci. 87, 37-55. doi:10.1016/j.jseaes.2014.02.012

Ueno, K., and Charoentitirat, T. (2011). "Carboniferous," in The Geology of Thailand. Editors M. F. Ridd, A. J. Barber, and M. J. Crow (London: The Geological Society), 71-136.

Uysal, I. T., Feng, Y.-x., Zhao, J.-x., Bolhar, R., Işik, V., Baublys, K. A., et al. (2011). Seismic Cycles Recorded in Late Quaternary Calcite Veins: Geochronological, Geochemical and Microstructural Evidence. Earth Planet. Sci. Lett. 303, 84-96. doi:10.1016/j.epsl.2010.12.039

Vattanasak, H., Chonglakmani, C., Feng, Q., and Morley, C. K. (2020). Chert Geochemistry, Depositional Setting, Stratigraphic and Structural Significance for the Permian Nong Pong Formation, Khao Khwang Fold and Thrust Belt, Saraburi, Thailand. J. Asian Earth Sci. 191, 104234. doi:10.1016/j.jseaes.2020.104234

Veizer, J., Ala, D., Azmy, K., Bruckschen, P., Buhl, D., Bruhn, F., et al. (1999). 87Sr/ $86 \mathrm{Sr}, \delta 13 \mathrm{C}$ and $\delta 18 \mathrm{O}$ Evolution of Phanerozoic Seawater. Chem. Geology. 161, 59-88. doi:10.1016/s0009-2541(99)00081-9

Wang, Z.-Y., Xin, Y.-Z., Gao, D.-M., Li, F.-M., Morgan, J., and Xing, B.-S. (2010). Microbial Community Characteristics in a Degraded Wetland of the Yellow River Delta. Pedosphere 20, 466-478. doi:10.1016/s1002-0160(10)60036-7

Waples, D. W., and Machihara, T. (1991). "Biomarkers for Geologists," in American Association of Petroleum Geologists Methods in Exploration Series, 91-99.
Warren, J. K., George, S. C., Hamilton, P. J., and Tingate, P. (1998). Proterozoic Source Rocks: Sedimentology and Organic Characteristics of the Velkerri Formation, Northern Territory, Australia. AAPG Bull. 82, 442-463. doi:10.1306/1d9bc435-172d-11d7-8645000102c1865d

Warren, J., Morley, C. K., Charoentitirat, T., Cartwright, I., Ampaiwan, P., Khositchaisri, P., et al. (2014). Structural and Fluid Evolution of Saraburi Group Sedimentary Carbonates, central Thailand: A Tectonically Driven Fluid System. Mar. Pet. Geol. 55, 100-121. doi:10.1016/ j.marpetgeo.2013.12.019

Wieldchowsky, C. C., and Young, J. D. (1985). "Regional Facies Variation in Permian Rocks of the Phetchabun Fold and Thrust Belt, Thailand," in Proceedings of the on Geology and Mineral Resources Development of North-Eastern Thailand 1985 Conference, Khon Kaen, Thailand (Khon Kaen, Thailand: Khon Kaen University), 41-55.

Wilkin, R. T., Barnes, H. L., and Brantley, S. L. (1996). The Size Distribution of Framboidal Pyrite in Modern Sediments: an Indicator of Redox Conditions. Geochim. Cosmochim. Acta 60 (20), 3897-3912. doi:10.1016/0016-7037(96) 00209-8

Wolff, G. A., Rukin, N., and Marshall, J. D. (1992). Geochemistry of an Early Diagenetic Concretion from the Birchi Bed. Org. Geochem. 19, 431-444. doi:10.1016/0146-6380(92)90010-u

Yan, Y., Huang, B., Zhang, D., Charusiri, P., and Veeravinantanakul, A. (2018). Paleomagnetic Study on the Permian Rocks of the Indochina Block and its Implications for Paleogeographic Configuration and Northward Drifting of Cathaysialand in the Paleo-Tethys. J. Geophys. Res. Solid Earth 123 (6), 4523-4538. doi:10.1029/2018jb015511

Yu, H., Zhou, X., Wang, J., Guo, C., Wei, H., and Chen, D. (2015). The Origin of Bedding-Parallel Fibrous Calcite Veins in the Lower Permian Chihsia Formation in Western Hubei Province, South China. Sci. Bull. 60 (20), 1778-1786. doi:10.1007/s11434-015-0903-z

Zanella, A., and Cobbold, P. R. (2012). "Beef: Evidence for Fluid Overpressure and Hydraulic Fracturing in Source Rocks During Hydrocarbon Generation and Tectonic Events: Field Studies and Physical Modelling," in Proceeding of the Geofluids VII international conference, Rueil-Malmaison, June, 2012.

Zhang, J., Jiang, Z., Jiang, X., Wang, S., Liang, C., and Wu, M. (2016). Oil Generation Induces Sparry Calcite Formation in Lacustrine Mudrock, Eocene of East China. Mar. Pet. Geol. 71, 344-359. doi:10.1016/ j.marpetgeo.2016.01.007

Zhang, J., Jiang, Z., Wang, S., Wang, R., Zhang, Y., and Du, W. (20221). BeddingParallel Calcite Veins as a Proxy for Shale Reservoir Quality. Mar. Pet. Geol. 127, 104975. doi:10.1016/j.marpetgeo.2021.104975

Conflict of Interest: Author KL was employed by the company PTT Exploration and Production.

The remaining authors declare that the research was conducted in the absence of any commercial or financial relationships that could be construed as a potential conflict of interest.

Publisher's Note: All claims expressed in this article are solely those of the authors and do not necessarily represent those of their affiliated organizations, or those of the publisher, the editors and the reviewers. Any product that may be evaluated in this article, or claim that may be made by its manufacturer, is not guaranteed or endorsed by the publisher.

Copyright (C) 2022 Chenrai, Assawincharoenkij, Warren, Sa-nguankaew, Meepring, Laitrakull and Cartwright. This is an open-access article distributed under the terms of the Creative Commons Attribution License (CC BY). The use, distribution or reproduction in other forums is permitted, provided the original author $(s)$ and the copyright owner(s) are credited and that the original publication in this journal is cited, in accordance with accepted academic practice. No use, distribution or reproduction is permitted which does not comply with these terms. 